\title{
Part-time strategies of women and men of childbearing age in the Netherlands and Australia
}

\author{
Mara A. Yerkes and Belinda Hewitt
}

\section{Introduction}

Scholars have argued that labour markets are segmented into primary and secondary markets, with insiders working in well-protected and well-paid jobs in the primary segment and outsiders working in more precarious, poorly paid jobs in the secondary segment (eg Dickens and Lang, 1993). More recently, this argument has been revisited because the prevalence of precarious employment continues to grow (Emmenegger et al, 2012b; Palier and Thelen, 2010; Prosser, 2016). Dualisation scholars contend that labour market outsiders are particularly affected by processes of globalisation, post-industrialisation and labour market liberalisation. Part-time work is often seen as an indicator of participation in a secondary labour market, yet this assumption may not always hold.

In the Netherlands, the 'part-time work champion' of the industrialised world (Visser, 2002; Yerkes, 2009), nearly two thirds of women and one fifth of men work part-time (OECD, 2017). Parttime work is highly regulated, and workers enjoy the same pro rata rights as full-time workers (Yerkes and Visser, 2006). On the one hand, dualisation might be absent as such high levels of protection are uncommon in other countries with high rates of part-time work. Australia also has relatively high levels of part-time employment, with $38.4 \%$ of women and $15.1 \%$ of men working part-time (OECD, 2017). However, in contrast to the Netherlands, part-time work conditions are less favourable, making dualisation more likely in Australia than the Netherlands. For example, Australian employees can often only reduce hours by changing jobs and shifting to lower-status employment sectors (Roeters and Craig, 2014). On the other hand, dualisation may be evident in both countries. Similar to Australia, women, and 
mothers in particular, use part-time work as a strategy to combine work and care (Yerkes, 2009).

Even though similar part-time trends are visible, particularly in relation to gender and parenthood, the conditions under which parttime work strategies are used differ. Therefore, the part-time work strategies of women and men of childbearing age in Australia and the Netherlands are explored in this chapter. We start by focusing on the part-time work strategies of both men and women: how do women and men differ in their part-time employment patterns? We then unpack the variation in women's part-time employment strategies: which drivers and mechanisms explain these seemingly comparable part-time employment strategies across the two countries? We examine these questions cross-sectionally using European Social Survey (ESS) data (from 2014) for the Netherlands and Household Income and Labour Dynamics in Australia (HILDA) data (from 2014) for Australia. Placed in a comparative context, these analyses provide insight into varying policy and cultural contexts in relation to parttime employment strategies and possible dualisation effects in both countries.

\section{The context of part-time work in the Netherlands and Australia}

Part-time work is highly gendered in both countries. In Australia, $38.4 \%$ of women work less than 30 hours a week; in the Netherlands, this holds true for nearly 60\% of women (OECD, 2017). While parttime work among men has increased slightly in both countries over the last two decades, men are much less likely to work part-time; in 2016, the figures were $15.1 \%$ for Australia and $18.7 \%$ in the Netherlands. While part-time work is a strategy used by women across all age groups in Australia and the Netherlands, men in the age range of 15-24 are much more likely to work part-time than men aged 2554, for example. Part-time work is also slightly higher for men near retirement age.

There is some evidence that part-time work as a work-family strategy could be changing in the Netherlands. In the past 15 years, the Dutch government has encouraged women, and mothers in particular, to take part in paid employment and work longer hours. Significant childcare improvements have been made (Yerkes, 2014), although some aspects, such as flexibility, affordability and quality, remain problematic (Yerkes and Javornik, 2018). Leave options, such as well-paid, gender-egalitarian parental leave or paid paternity leave 
of more than a few days, remain limited (Yerkes and Den Dulk, 2015). It is not clear what mothers' and fathers' strategies for combining work and care are in this mixed work-family policy environment. For these reasons, it is necessary to reconsider the strategies of women and men of childbearing age working part-time in the Netherlands.

Australia provides an interesting comparison. With the exception of Switzerland, the Netherlands and Australia share the highest rate of part-time work in industrialised countries (OECD, 2017). In line with developments in the Netherlands, trend data from the Organisation for Economic Co-operation and Development (OECD) suggest that Australian women aged 25-54 are also increasingly working full-time (30 hours or more a week). There have also been minor increases in the percentage of men aged 25-54 working part-time, from 5.5\% in 2001 to $7.7 \%$ in 2016 . Their regulation of part-time work differs, but work-family policies in both countries are similarly gendered and in flux. Significant improvements have been made in childcare quality in Australia (Whiteford, 2015), for example, but issues around accessibility, availability, affordability and flexibility remain (Baxter and Hand, 2016; Yerkes and Javornik, 2018). Leave options, including paid parental leave (Martin et al, 2011) and paid leave for fathers and partners (Martin et al, 2014), have improved the work-family situation by providing most families with access to leave payments. Yet, gendered work-care patterns remain in place during the first 12 months of a child's life (Rose et al, 2015). Thus, similar to the Netherlands, considerable changes have taken place in the workfamily policy landscape in recent years, but various obstacles remain, warranting a closer look at women's and men's strategies for combining work and care in these policy environments.

\section{Dualisation in the Dutch and Australian contexts}

One purpose of this edited volume is to determine the extent to which part-time work segregates labour markets into insiders and outsiders. While dualisation is defined by a differentiation in rights and entitlements or access to services between part-time and full-time workers (Emmenegger et al, 2012a), such differentiation may also take place between part-time workers. As a result, certain workers are more adversely affected by labour market and welfare state changes than others (Palier and Thelen, 2010; Emmenegger et al, 2012b). Dualisation can also lead to a narrowing of insider groups and a widening of outsider groups, whereby some people who were previously considered insiders become outsiders. It is also possible 
that labour market and welfare state changes or an absence of state intervention in some areas will produce new forms of institutional dualism (Palier and Thelen, 2010; Emmenegger et al, 2012a).

In this chapter, we are interested in bridging dualisation theory with work-family theory. Parents often rely on flexible working forms to reconcile the demands of paid employment and the care for (young) children (Den Dulk et al, 2005; Miani and Hoorens, 2014). Flexibility in start and end times, the ability to temporarily reduce one's hours, or working part-time are all forms of flexibility sought by parents. Despite the increased availability of flexible work policies to both mothers and fathers (Hegewisch, 2009; Hegewisch and Gornick, 2011), mothers overwhelmingly make greater use of flexible work forms (Miani and Hoorens, 2014). Part-time work, in particular, developed as a means for mothers to combine work and care (O'Reilly and Fagan, 1998; Yerkes, 2009), and remains a gendered phenomenon (Hegewisch and Gornick, 2011; Miani and Hoorens, 2014).

The negative effects of gendered patterns in part-time and other flexible work forms are well documented. Women face prospects of lower earnings (Bardasi and Gornick, 2008; Budig and Hodges, 2010), lower occupational status (Dex et al, 2008), reduced management opportunities and delayed career trajectories (Williams et al, 2013). Depending upon the length of time spent in part-time employment, women also face reduced entitlements to social protection arrangements (Dekker, 2007; Emmenegger et al, 2012a). Similarly, working conditions and job quality are found to be lower for part-time workers (Gallie et al, 2016).

Given the overwhelmingly negative consequences of part-time work, researchers continue to ask why mothers accept such working arrangements. Part-time workers may be more satisfied with employment than full-time workers because they can enjoy the positive aspects of employment without the added stress of full-time hours, particularly in combination with household or care responsibilities (Treas et al, 2011). Additionally, part-time work may be accepted because it fits parents', and in particular mothers', care preferences in some countries (eg Lewis et al, 2008). From this perspective, the gender difference in part-time work may be unequal yet equitable as mothers view these employment outcomes as fair (McDonald, 2013). Indeed, recent evidence from Australia suggests that mothers entering into flexible working arrangements upon returning to work after childbirth often do not see such arrangements as unfair (Yerkes et al, 2017), dependent upon their educational level and career prospects. In occupations where part-time work was largely expected following 
childbirth, Australian mothers rarely questioned the fairness of flexible working arrangements. In other words, in female-typed occupations, motherhood penalties are already built in and accepted (Yerkes et al, 2017: 487). The presence of such structural constraints suggests that one should be critical of viewing part-time work as gender equitable in this case (McDonald, 2013: 983). ${ }^{1}$ In Australia, then, it appears that structural constraints create a dualised labour market in which significant gender differences, as well as occupational differences, exist.

Structural opportunities and constraints at the country and individual levels are equally important when understanding parents', and in particular mother's, employment patterns (cf Kangas and Rostgaard, 2007). Parents' employment decisions are shaped by what they view as possible in a given cultural and institutional context (Hobson, 2016), as well as by a complex interaction of individual, community-level and social factors (cf Hobson, 2014; Annink, 2017; Javornik and Kurowska, 2017; Yerkes and Javornik, 2018). Yet, it has proven empirically difficult to ascertain the extent to which the institutional context, that is, policy and legal frameworks, matter for part-time work and other flexible work forms. Scholarship in the field of gender and employment studies produces mixed empirical results on the extent to which institutional frameworks ameliorate the negative effects associated with part-time work. Treas and colleagues (2011) find that in countries with generous welfare states, where family living standards are less dependent on women's working hours, parttime work appears to allow women to benefit from the 'best of both worlds': employment and motherhood/homemaking. In contrast, the five-country study by Roeters and Craig (2014) concludes that the country of residence is not important for shaping the effects of parttime work. Given these mixed empirical results, the conclusion of Hegewisch (2009: ix) is possibly the most plausible: while statutory frameworks around part-time work and other flexible work forms matter, such frameworks are no 'magic bullet for changing gender specific flexible work patterns'.

In this chapter, we partially contribute to this debate by examining the extent to which these gender-unequal part-time work patterns reflect insider-outsider labour market effects (eg based on gender and occupational effects) by comparing a country with high protection of part-time workers (the Netherlands) with a country with minimal protection of part-time workers (Australia). While we cannot directly control for country-level differences in our two-country study, we do have two countries with different institutional contexts. In the Netherlands, the regulation of part-time work through anti- 
discrimination legislation and rights to adjust working hours means that part-time workers in the Netherlands have better employment conditions than workers in other countries (Yerkes and Visser, 2006; Bartoll et al, 2014). Given the higher protection afforded to part-time work and part-time workers, we should expect that the gender and occupational effects generally thought to occur in other countries will be lower (eg in the Netherlands) than in countries where part-time workers do not have similar protection under the law (eg in Australia).

\section{Data and methodology}

We rely on two different data sets for the analyses in this chapter. For the Netherlands, we use data from the seventh round of the ESS (ESS 2014/15) (for details, see: www.europeansocialsurvey.org). ESS data collection is cross-sectional, starting in 2001. Data are collected every two years using face-to-face interviews. Fieldwork for Round 7 was carried out in the Netherlands between September 2014 and January 2015, resulting in a total sample of 1,919 respondents aged 15 and over (response rate $=58.6 \%)$.

The data for Australia come from wave 14 (2014) of the HILDA survey. HILDA is a longitudinal panel survey that has been running since 2001. Wave 1 comprised 7,682 households and 13,969 individuals. Households were selected using a multi-stage sampling approach, and a 66\% response rate was achieved (Summerfield et al, 2016). Within households, data were collected from each person aged over 15 years using face-to-face interviews and self-completed questionnaires, and achieved a 92\% response rate of household members (Watson and Wooden, 2002). Using the same approach, in 2011, a top-up sample of 2,153 households (63\% response rate) and 4,009 individuals (93.7\% response rate) was collected. HILDA is an evolving panel, and the sample includes any new household members resulting from changes in the composition of the original households.

For the current analyses, we included all respondents in HILDA wave $14(n=17,512)$ and ESS data for $2014(n=1,919)$, with the following restrictions. We restricted the analytic sample to men and women in paid employment for at least one hour per week (HILDA $n=10,946$; ESS $n=1,778$ ). To capture men and women at their prime working and child-rearing ages, we further limited the sample to those aged between 18 and 55 (HILDA $n=8,887$; ESS $n=972$ ). We excluded men and women who were self-employed or working in family businesses (HILDA $n=1,010$; ESS $n=116$ ), and those 
employed in the defence force (HILDA $n=16$; $\operatorname{ESS} n=1$ ). In addition, we dropped cases where there were missing data on the dependent variable (HILDA $n=22$; ESS $n=0$ ) and key independent variables (HILDA $n=12$; ESS $n=49$ ). After these limitations and exclusions, the final analytic sample for HILDA comprised 7,769 respondents: 3,893 women and 3,876 men. For the ESS, the final analytic sample comprised 851 respondents: 472 women and 303 men. Descriptive information on both samples can be found in Table 11.1.

\section{Measures}

\section{Dependent variables}

We used two dependent variables: one for the analysis comparing men and women; and one for the analysis of women only. Due to the very low numbers of men working part-time, we used a simple dichotomous measure of working (1) full-time (35 hours+ [reference]) or (2) part-time (less than 35 hours per week). For women, we further expanded the measure for part-time hours to capture more refined groupings of part-time employment that better reflect women's work, including: (1) full-time (reference); (2) long part-time hours (20 to 34 hours per week); and (3) short part-time hours (1 to 19 hours per week).

\section{Independent variables}

We also include a range of measures capturing socio-demographic, employment and family characteristics. Part-time work strategies vary across the life course and educational levels. We include a categorical measure for age in all models (18-24 [reference], 25-34, 35-44, 4555) and we use the International Standard Classification of Education (ISCED) to develop a measure of (1) low (indicating no secondary education), (2) medium (indicating completed secondary education) and (3) high education (indicating completed tertiary education). We also include a measure for household income, broken down into quintiles from the whole sample population (not the restricted analytic sample), ranging from (1) the bottom $20 \%$ (reference) to (5) the top $20 \%$ of income. ${ }^{2}$ For the Netherlands, this measure is based on the household's total net income (of all household members) from all sources (eg wages, pensions, benefits). For Australia, this measure is based on total household disposable income (net after tax) for the financial year (July 2013 to June 2014) from all sources, including 
Table 11.1: Dependent variables and key independent variables, descriptive statistics for the Netherlands (ESS 2014) and Australia (HILDA 2014)

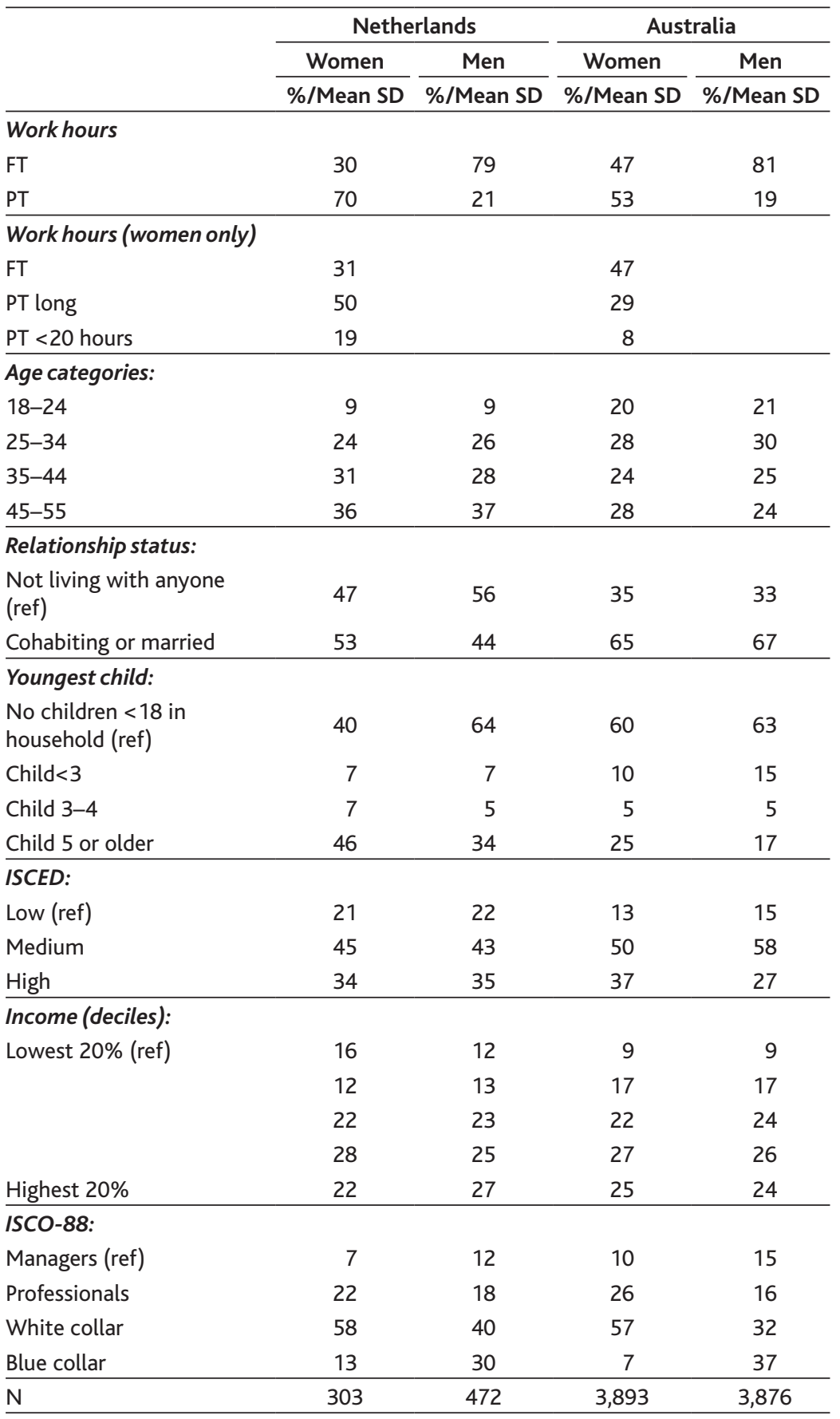


wages, business income, pensions and benefits. Family characteristics, such as marital status and the presence of pre-school children in the household, are crucial for understanding differences in part-time strategies (O'Reilly and Fagan, 1998). In our models, relationship status indicates (1) not in a live-in relationship (reference) and (2) cohabiting or married. We measure the age of the youngest child in the household, including (1) no children under 18 in the household (reference), (2) child under three years of age, (3) child between three and four years of age, and (4) child aged five or older, as an indicator for the presence of a pre-school child aged four or under in the household $(1=$ yes $)$. Lastly, two key employment characteristics include occupation and contract type. Part-time work structures are also often built into particular occupations, creating 'mommy tracks' that penalise mothers through lower pay and poor career prospects (eg Kalleberg, 2000). This occupational effect is particularly prevalent among women, demonstrating the intersection between gender and class effects in employment (Korpi, 2010). Occupation was initially coded using the International Standard Classification of Occupations 88 (ISCO-88) two-digit coding, but due to small numbers in some groups, the occupations were collapsed to (1) managers (ISCO-88 10 to 13 [reference]), (2) professionals (ISCO-88 20 to 24), (3) whitecollar workers (ISCO-88 30 to 59) and (4) blue-collar workers (ISCO-88 60 to 99).

\section{Analytical strategy}

Our analysis proceeded in two stages. In the first stage, we estimated a logistic regression model to examine the likelihood of working part-time versus full-time and to compare the characteristics of men and women who work part-time. We estimated one model including all covariates. In the second stage, we used a multinomial logistic regression to compare women who were working long part-time hours and women who were working short part-time hours with women who were working full-time. The models were estimated separately for the Netherlands and Australia. Following Mood (2010) and Connelly (Connelly et al, 2016), we present our results as average marginal means to ease their interpretation. Coefficients can thus be interpreted as a discrete change from the base level holding all other measures constant at their means. The use of average marginal means not only allows for a more straightforward interpretation of the results, but also allows us to make comparisons across samples and groups (Mood, 2010: 78). 


\section{Results}

Men and women are not equally likely to work part-time in the Netherlands and what predicts part-time working differs for women and men (see Table 11.2). The results indicate that age is negatively and significantly associated with working part-time. Men aged 35 and older in the Netherlands, and men and women aged 25 and older in both countries, are significantly less likely to work part-time than men and women aged 18-24. Men who are living with a partner in Australia are significantly less likely to work part-time than men who are not living with a partner. Relationship status is not significantly associated with working part-time for Australian women. In contrast, relationship status is not significantly associated with working parttime for men in the Netherlands, but married and cohabitating Dutch women are more likely to work part-time than women not married or cohabitating. Having a child in the household is significantly and positively associated with women working part-time, but not for men. This factor is significant in both countries and the magnitude of this association is larger when children are (very) young. Education is not significant for men or women in either country. Women with a secondary education in Australia are less likely to work part-time than women with less than a secondary education, but this effect just borders on significance. Income is strongly and negatively associated with part-time work in Australia. This contrasts with findings in the Netherlands, which show that households where Dutch women work part-time, holding all other measures constant at their means, are more likely to be in the lowest income quintile (lowest $20 \%$ of household incomes). Women in the highest quintile of income in the Netherlands are strongly and significantly less likely to work part-time than women from the lowest income quintile. This result could indicate that in higher-income households, men and women both work full-time. Occupation is significantly associated with working part-time for women in both countries. Compared to managers, women in all other occupation groups are significantly more likely to be working parttime. Men across all occupational groups in Australia are more likely to be working part-time in comparison to managers. In the Netherlands, this only holds true for white-collar workers. ${ }^{3}$

In Table 11.3, we present the results of comparing women in the Netherlands and Australia working long or short part-time hours versus full-time. When distinguishing between long and short parttime hours, there are some interesting similarities and differences for women compared to the first stage of analysis, where all part-time work 
Table 11.2: Average marginal means of characteristics associated with part-time employment (reference full-time) for employed men and women in the Netherlands (ESS 2014) and Australia (HILDA 2014)

\begin{tabular}{|c|c|c|c|c|c|c|c|c|}
\hline & \multicolumn{4}{|c|}{ Netherlands } & \multicolumn{4}{|c|}{ Australia } \\
\hline & \multicolumn{2}{|l|}{ Men } & \multicolumn{2}{|c|}{ Women } & \multicolumn{2}{|l|}{ Men } & \multicolumn{2}{|l|}{ Women } \\
\hline & Marginal mean ${ }^{\mathrm{a}}$ & SE & Marginal mean & SE & Marginal mean & SE & Marginal mean & SE \\
\hline \multicolumn{9}{|l|}{ Age categories: } \\
\hline 18-24 (ref) & - & & - & & - & & - & \\
\hline $25-34$ & $-0.17 \dagger$ & 10 & $-0.17^{* *}$ & .06 & $-0.19 * * *$ & .02 & $-0.25^{* * *}$ & .02 \\
\hline $35-44$ & $-0.20 \dagger$ & .10 & $-0.23 * * *$ & .06 & $-0.20 * * *$ & .02 & $-0.21^{* * *}$ & .02 \\
\hline $45-55$ & $-0.21^{*}$ & .10 & $-0.16 * *$ & .06 & $-0.20 * * *$ & .02 & $-0.16 * * *$ & .02 \\
\hline \multicolumn{9}{|l|}{ Relationship status: } \\
\hline Not living with anyone (ref) & - & & - & & - & & - & \\
\hline Cohabiting or married & -0.06 & .05 & $0.10^{*}$ & .05 & $-0.07^{* * *}$ & .02 & 0.01 & .02 \\
\hline \multicolumn{9}{|l|}{ Youngest child: } \\
\hline No children $<18$ in household (ref) & - & & - & & - & & - & \\
\hline Child $<3$ & -0.06 & .08 & $0.28^{* * *}$ & .07 & -0.01 & .02 & $0.36^{* * *}$ & .02 \\
\hline Child 3-4 & -0.09 & .08 & $0.23 * *$ & .08 & -0.03 & .03 & $0.39 * * *$ & .03 \\
\hline Child 5 or older & 0.01 & .07 & $0.21^{* * *}$ & .05 & -0.03 & .02 & $0.24^{* * *}$ & .02 \\
\hline \multicolumn{9}{|l|}{ ISCED: } \\
\hline Low (ref) & - & & - & & & & & \\
\hline Medium & 0.03 & .05 & 0.04 & .06 & -0.01 & .02 & $-0.05 \dagger$ & .02 \\
\hline High & 0.04 & .07 & -0.03 & .07 & 0.01 & .02 & -0.04 & .03 \\
\hline
\end{tabular}


Table 11.2: Average marginal means of characteristics associated with part-time employment (reference full-time) for employed men and women in the Netherlands (ESS 2014) and Australia (HILDA 2014) (continued)

\begin{tabular}{|c|c|c|c|c|c|c|c|c|}
\hline & \multicolumn{4}{|c|}{ Netherlands } & \multicolumn{4}{|c|}{ Australia } \\
\hline & \multicolumn{2}{|l|}{ Men } & \multicolumn{2}{|c|}{ Women } & \multicolumn{2}{|l|}{ Men } & \multicolumn{2}{|l|}{ Women } \\
\hline & Marginal mean ${ }^{\mathrm{a}}$ & SE & Marginal mean & SE & Marginal mean & SE & Marginal mean & SE \\
\hline \multicolumn{9}{|l|}{ Income (deciles): } \\
\hline \multirow[t]{4}{*}{ Lowest 20\% (ref) } & - & & - & & - & & - & \\
\hline & -0.01 & .09 & $-0.12 \dagger$ & .07 & $-0.10 * * *$ & .02 & $-0.15^{* * *}$ & .03 \\
\hline & -0.13 & .08 & $-0.17^{* *}$ & .06 & $-0.10^{* * *}$ & .02 & $-0.15^{* * *}$ & .03 \\
\hline & -0.06 & .08 & $-0.15 t$ & .06 & $-0.14^{* * *}$ & .02 & $-0.19 * * *$ & .03 \\
\hline Highest 20\% & -0.07 & .09 & $-0.25 * * *$ & .07 & $-0.12 * * *$ & .02 & $-0.20 * * *$ & .03 \\
\hline \multicolumn{9}{|l|}{ ISCO-88: } \\
\hline Managers (ref) & - & & - & & - & & - & \\
\hline Professionals & 0.07 & .07 & $0.24^{*}$ & .09 & $0.04^{* *}$ & .02 & $0.23^{* * *}$ & .03 \\
\hline White collar & $0.14^{*}$ & .06 & $0.29 * *$ & .10 & $0.18^{* * *}$ & .02 & $0.34 * * *$ & .02 \\
\hline Blue collar & 0.06 & .07 & $0.26^{*}$ & .12 & $0.05^{* *}$ & .02 & $0.35^{* * *}$ & .04 \\
\hline $\mathrm{N}$ & 303 & & 472 & & 3,876 & & 3,893 & \\
\hline
\end{tabular}

Notes: a Discrete change from the base level holding all other measures constant at their means.

${ }^{\dagger} p<.10 ;{ }^{*} p<.05 ; * * p<.01 ; * * * p<.001$. 
Table 11.3: Average marginal means of characteristics associated with long part-time hours and short part-time hours (reference full-time) for employed women in the Netherlands (ESS 2014) and Australia (HILDA 2014)

\begin{tabular}{|c|c|c|c|c|c|c|c|c|}
\hline & \multicolumn{4}{|c|}{ Netherlands } & \multicolumn{4}{|c|}{ Australia } \\
\hline & \multicolumn{2}{|c|}{ Long part-time hours } & \multicolumn{2}{|c|}{$<20$ part-time hours } & \multicolumn{2}{|c|}{ Long part-time hours } & \multicolumn{2}{|c|}{$<20$ part-time hours } \\
\hline & Marginal mean & SE & Marginal mean & SE & Marginal mean & SE & Marginal mean & SE \\
\hline \multicolumn{9}{|l|}{ Age categories: } \\
\hline $18-24$ & - & & - & & - & & - & \\
\hline $25-34$ & $0.28 * *$ & .08 & $-0.45^{* * *}$ & .08 & -0.02 & .02 & $-0.22 * * *$ & .02 \\
\hline $35-44$ & $0.25^{* *}$ & .08 & $-0.50 * * *$ & .08 & 0.02 & .03 & $-0.22 * * *$ & .03 \\
\hline$\underline{45-55}$ & $0.35^{* * *}$ & .07 & $-0.51 * * *$ & .07 & $0.07^{* *}$ & .02 & $-0.23 * * *$ & .02 \\
\hline \multicolumn{9}{|l|}{ Relationship status: } \\
\hline Not living with anyone (ref) & - & & - & & - & & - & \\
\hline Cohabiting or married & -0.06 & .05 & $0.17^{* * *}$ & .04 & $0.06^{* *}$ & .01 & $-0.04 * *$ & .02 \\
\hline \multicolumn{9}{|l|}{ Youngest child: } \\
\hline No children $<18$ in household (ref) & - & & - & & - & & - & \\
\hline Child $<3$ & $0.29 * *$ & .09 & -0.01 & .07 & $0.11^{* * *}$ & .03 & $0.24^{* * *}$ & .03 \\
\hline Child 3-4 & $0.25^{* *}$ & .09 & -0.02 & .06 & $0.16^{* * *}$ & .03 & $0.23 * * *$ & .03 \\
\hline Child 5 or older & $0.15^{* *}$ & .06 & 0.06 & .04 & $0.12^{* * *}$ & .02 & $0.13^{* * *}$ & .02 \\
\hline \multicolumn{9}{|l|}{ ISCED: } \\
\hline Low (ref) & - & & - & & - & & - & \\
\hline Medium & 0.02 & .06 & 0.03 & .04 & 0.001 & .02 & $-0.05^{*}$ & .02 \\
\hline High & 0.03 & .07 & -0.06 & .05 & 0.01 & .03 & $-0.06^{*}$ & .02 \\
\hline
\end{tabular}


Table 11.3: Average marginal means of characteristics associated with long part-time hours and short part-time hours (reference full-time) for employed women in the Netherlands (ESS 2014) and Australia (HILDA 2014) (continued)

\begin{tabular}{|c|c|c|c|c|c|c|c|c|}
\hline & \multicolumn{4}{|c|}{ Netherlands } & \multicolumn{4}{|c|}{ Australia } \\
\hline & \multicolumn{2}{|c|}{ Long part-time hours } & \multicolumn{2}{|c|}{$<20$ part-time hours } & \multicolumn{2}{|c|}{ Long part-time hours } & \multicolumn{2}{|c|}{$<20$ part-time hours } \\
\hline & Marginal mean & SE & Marginal mean & SE & Marginal mean & SE & Marginal mean & SE \\
\hline \multicolumn{9}{|l|}{ Income (deciles): } \\
\hline \multirow[t]{4}{*}{ Lowest $20 \%$ (ref) } & - & & - & & - & & - & \\
\hline & -0.12 & .09 & 0.003 & .07 & $-0.07^{*}$ & .03 & $-0.08^{* *}$ & .03 \\
\hline & $-0.19 *$ & .08 & 0.001 & .06 & $-0.08^{*}$ & .03 & $-0.07^{*}$ & .02 \\
\hline & -0.08 & .08 & -0.08 & .06 & $-0.10^{* *}$ & .03 & $-0.09 * *$ & .03 \\
\hline Highest 20\% & $-0.20^{*}$ & .08 & -0.05 & .07 & $-0.12^{* * *}$ & .03 & $-0.08^{* *}$ & .03 \\
\hline \multicolumn{9}{|l|}{ ISCO-88: } \\
\hline Managers (ref) & - & & - & & - & & - & \\
\hline Professionals & 0.19 & .10 & 0.06 & .05 & $0.14^{* * *}$ & .02 & $0.09 * * *$ & .02 \\
\hline White collar & 0.15 & .10 & $0.15^{* *}$ & .05 & $0.20 * * *$ & .02 & $0.14^{* * *}$ & .02 \\
\hline Blue collar & 0.05 & .11 & $0.22 * *$ & .07 & $0.19 * * *$ & .03 & $0.16^{* * *}$ & .03 \\
\hline $\mathrm{N}$ & \multicolumn{4}{|c|}{472} & \multicolumn{4}{|c|}{3,893} \\
\hline
\end{tabular}

Notes: a Discrete change from the base level holding all other measures constant at their means.

${ }^{\dagger} p<.10 ;{ }^{*} p<.05 ; * * p<.01 ; * * * p<.001$. 
hours were treated uniformly. Age is no longer uniformly significantly and negatively associated with part-time work. In the Netherlands, age is positively associated with long part-time work hours but negatively associated with short part-time work hours. This effect likely reflects the prevalence of short part-time work hours among young people in the Netherlands, suggesting that women over the age of 24 are more likely to work long part-time hours. In Australia, age remains significantly and negatively associated with working short part-time hours but is not significantly associated with long part-time work hours, except for women aged 45-55, who are more likely to work long part-time hours in comparison to full-time.

In further contrast to the simplified full-time/part-time model, living with a partner is positively and significantly associated with working long part-time hours in Australia, but negatively and significantly associated with working short part-time hours. In the Netherlands, relationship status only matters for short part-time work hours. Married and cohabitating Dutch women are significantly more likely to work short part-time hours in comparison to unmarried/ non-cohabitating women. Having children under 18 in the household remains associated with working part-time in Australia, both short hours and long hours. In the Netherlands, however, having children under 18 is only positively and significantly associated with working longer part-time hours. In contrast to the simplified model, women with higher levels of education are significantly less likely to work short part-time hours in Australia. Higher household income is significantly and negatively associated with both forms of part-time work in Australia. However, in the Netherlands, household income is only significantly and negatively associated with long part-time work hours for women in the third and fifth highest quintiles. Lastly, in Australia, occupation remains significantly and positively associated with part-time work. In comparison to women who are in managerial occupations, those in all other occupation groups are significantly more likely to work part-time. This association is stronger for long parttime hours than short part-time hours. In the Netherlands, however, occupation is only significantly associated with short part-time work hours. Women in white- and blue-collar occupations are significantly more likely than managers to work short part-time hours. ${ }^{4}$

\section{Conclusion and discussion}

The dualisation of labour markets creates a situation in which one group of workers enjoys significantly better protection, wages, security 
and/or labour market prospects than another group of workers (Palier and Thelen, 2010; Emmenegger et al, 2012a). In many countries, part-time work may be associated with a secondary labour market, with part-time workers having less protection, lower wages, more insecurity and fewer labour market prospects than full-time workers. Yet, this chapter started from the premise that in the Netherlands, where part-time work is highly regulated and protected, there might be less evidence of dualisation than in other countries where part-time work is less regulated and/or protected.

In our comparison with Australia, we see mixed results. Some of our findings indicate that the part-time work context of Australia may differ from that of the Netherlands. For example, in our comparison of men and women, full-time work seems to be more important for household income in Australia than in the Netherlands. This suggests that the wages and salaries of part-time workers in the Netherlands may be better than in Australia, or that part-time work is distributed more evenly throughout the household income distribution in the Netherlands. However, further research is needed to determine the validity of such assumptions, particularly given conflicting empirical evidence on the wage effects of part-time work for Australian mothers (Hosking, 2010; Preston and Yu, 2015). Education appears to be a more important driver of part-time work for women in Australia than in the Netherlands, particularly for short part-time work hours. This finding could reflect the normalisation of part-time work among women of all educational levels in the Netherlands, although previous research suggests that more highly educated women are likely to work more hours as their earnings capacity is higher (Portegijs and Keuzenkamp, 2008; Portegijs and Van den Brakel, 2016).

In contrast to the Netherlands, mothers of young children in Australia are more likely to be in short part-time work, which suggests that motherhood is less compatible with longer working hours than in the Netherlands. We also see opposite findings for the Netherlands and Australia in terms of relationship status. Married and cohabitating women are more likely to work short part-time jobs in the Netherlands, whereas the opposite is true for Australia. Thus, our comparative analysis implies there is stronger evidence for dualisation in Australia.

On the other hand, our findings suggest that even in the Netherlands, where part-time work is well protected, dualisation exists. We find significant gender and occupational differences in the predictors of full- and part-time work. In the Netherlands, having children increases women's chances of working part-time, but not men's. Gender norms 
around parenthood continue to be an important driver of differences between full-time and part-time work for men and women (Yerkes and Den Dulk, 2015). In Australia, occupation is also an important driver of dualisation between part-time and full-time work (partly mediated by education for Australian mothers), and this effect appears to be consistent across both forms of part-time work. These findings are in line with previous research from Bardasi and Gornick (2008), who show clear occupational segregation into part-time work, which is greater in the more liberal welfare regimes of the US and the UK.

Crucially, our findings for the Netherlands suggest that dualisation also exists within part-time work. We find that while mothers of (particularly young) children are likely to work long part-time hours in the Netherlands (eg 'equalised' part-time workers, see Chapter 1), short part-time work is primarily driven by occupation (mediated, in part, by education), relationship status and age. ${ }^{5}$ These findings point to a possible dualisation between women in more precarious short part-time work, who are primarily young, in white- and blue-collar occupations, and/or married/cohabitating, versus women in long part-time positions, who are 25 or older, mothers of (young) children and/or professionals working longer part-time hours. In the best-case scenario, women in these short part-time jobs are semi-secured or equalised (see Chapter 1), protected by part-time work regulations in the Netherlands. Despite these regulations, short part-time work carries significantly greater risks of long-term economic and career disadvantage for women than long part-time work or full-time work, even if it is voluntary and performed under (relatively) good working conditions.

Some caution is needed when interpreting these findings. To make the data sets comparable, we have excluded contract type. Further research is needed to determine the extent to which these apparent dual labour markets are a reflection of gender and occupational differences versus differences in permanent, fixed-term or casual contracts. Additionally, the sample size for the Netherlands is quite small. While the ESS data allow for a comparison with Australian data, our focus on women and men of childbearing age led to the exclusion of a large number of respondents. We are also limited by the crosssectional nature of our analysis. Future research is needed to look at the causality of the relationships examined here, for example, through longitudinal panel analysis. While the Australian HILDA data offer a high-quality longitudinal panel, Dutch panel data are problematic from a comparability standpoint, particularly in relation to variables on occupation, which is a key variable in the analysis of part-time work. 
Despite these limitations, our analysis offers important insights for the debate on dualisation and part-time work and work-family scholarship. While the protection offered to part-time workers in the Netherlands is relatively unique, it does not appear to prevent dualised labour markets from developing. As argued by Bardasi and Gornick (2008), the presence of these comparative differences in part-time work highlight the need for a better understanding of the effect of workfamily and employment policies in maintaining or countering such dualisation effects. For example, the greater importance of income in the Australian models suggests that part-time work legislation in the Netherlands is possibly more effective in protecting the wages of part-time workers. Yet, Dutch legislation does not appear to be able to prevent occupational or age segregation within part-time work. While not denying the importance of protective legislation for creating decent working conditions for part-time workers (Yerkes and Visser, 2006), it suggests that further vigilance is needed, even in a country where part-time work is well protected. This vigilance is also warranted in preventing possible new, intersectional forms of dualisation, particularly among young women, or migrant women, who are increasingly taking part in the labour market.

These findings have important theoretical implications as well. Work-family theory suggests that parents, and mothers in particular, rely on flexible working forms, such as part-time work, to reconcile the demands of paid employment and the care for (young) children (Den Dulk et al, 2005; Miani and Hoorens, 2014). The gendered nature of part-time work (Hegewisch and Gornick, 2011; Miani and Hoorens, 2014) leads to dualisation in work between men and women, as confirmed by our findings in both countries.

Additionally, our finding that dualisation appears to exist within parttime work in the Netherlands has consequences for how part-time work is viewed from a work-family perspective. This finding suggests that a reliance on part-time work to achieve flexibility in reconciling work and family demands is driven not only by gender, but also by age and class. Thus, while work-family scholarship demonstrates that part-time work may suit mothers' work-care preferences (eg Lewis et al, 2008) or meet their flexibility needs, and that mothers often view these arrangements as fair (McDonald, 2013; Yerkes et al, 2017), structural constraints remain. There is a continued need for concern regarding gender and class equality in part-time work strategies for reconciling work and care. 


\section{Notes}

1 The gender equity of part-time work can also be questioned in relation to whether part-time work is supply- or demand-driven, and hence whether part-time work is meeting employees' or employers' needs (Kalleberg, 2000).

2 Ideally, we would include partner income rather than household income because while household income may predict part-time employment, part-time employment may also cause variation in household income. However, ESS data do not include information on partner income.

3 Occupational effects may be partly mediated by education. In further analysis (not included here), we examined whether education was significant without controlling for occupation. We found that education became significant for Australian women, where women with medium and high levels of education were significantly less likely to be working part-time, but the results did not change for Australian men, or for men and women in the Netherlands.

4 In further analysis excluding occupation, for Australian women, the effects of education become larger and more significant. For Dutch women, the results change: women with high levels of education are significantly less likely to be working short part-time hours. This suggests that occupation may also be partly mediated by education here as well. Results are available from the authors.

5 Our findings on age are in line with OECD data, which show that young adults are increasingly likely to work part-time. In 2001, more than one third (34.2\%) and less than half (46.8\%) of men aged 15-24 worked part-time in Australia and the Netherlands, respectively. This percentage grew to $42.5 \%$ in Australia and 64\% in the Netherlands by 2016. Among young women, part-time work has also become the norm. In 2001, just under half (48.6\%) of Australian women aged 15-24 worked part-time compared to $58.7 \%$ in the Netherlands. These figures are now $55.6 \%$ and an overwhelming $79.2 \%$, respectively. The large increase in part-time work among young adults has gone hand-in-hand with an increase in temporary work forms and precarious employment for young people, which can have significant detrimental effects on their transition to adulthood (Fagan et al, 2012; Knijn, 2012). Recent evidence from the Netherlands suggests that for some young women, this precarious position is temporary (Merens and Bucx, 2018). As young women progress in their career, they are able to move out of 'underemployment' (see Chapter 1) into jobs with more hours. In both the Netherlands and Australia, underemployment among young women also appears to shift towards 'equalised' part-time jobs as they have children and then 'choose' to work fewer hours (Cassidy and Parsons, 2017; Merens and Bucx, 2018). These age-related part-time work 
questions deserve further attention in dualisation research but are beyond the scope of this chapter.

\section{References}

Annink, A. (2017) 'From social support to capabilities for the worklife balance of independent professionals', Journal of Management $\mathcal{E}$ Organization, 23(2): 258-76.

Bardasi, E. and Gornick, J.C. (2008) 'Working for less? Women's parttime wage penalties across countries', Feminist Economics, 14(1): 37-72.

Bartoll, X., Cortès, I. and Artazcoz, L. (2014) 'Full- and part-time work: gender and welfare-type differences in European working conditions, job satisfaction, health status, and psychosocial issues', Scandinavian Journal of Work, Environment \& Health, 40(4): 370-9. Available at: http://doi.org/10.5271/sjweh.3429

Baxter, J. and Hand, K. (2016) Flexible child care: key findings from the AIFS evaluation of the child care flexibility trials, Melbourne: Australian Institute of Family Studies.

Budig, M.J. and Hodges, M.J. (2010) 'Differences in disadvantage: variation in the motherhood penalty across white women's earnings distribution', American Sociological Review, 75(5): 705-28. Available at: http://doi.org/10.1177/0003122410381593

Cassidy, N. and Parsons, S. (2017) 'The rising share of part-time employment', The Reserve Bank of Australia Bulletin, September, pp 19-26.

Connelly, R., Gayle, V. and Lambert, P.S. (2016) 'Statistical modelling of key variables in social survey data analysis', Methodological Innovations, 9: 1-17. Available at: http://doi.org/10.1177/2059799116638002

Dekker, R. (2007) 'Non-standard employment and mobility in the Dutch, German and British labour market', Universiteit van Tilburg, Tilburg.

Den Dulk, L., Peper, A. and Van Doorne-Huiskes, A. (2005) 'Work and family life in Europe: employment patterns of working parents across welfare states', in A. Peper, A. van Doorne-Huiskes and L. den Dulk (eds) Flexible working, organizational change and the integration of work and personal life, Cheltenham: Edward Elgar, pp 13-38.

Dex, S., Ward, K. and Joshi, H. (2008) 'Changes in women's occupations and occupational mobility over 25 years', in J. Scott, S. Dex and H. Joshi (eds) Women and employment: changing lives and new challenges, Cheltenham: Edward Elgar, pp 54-80. 
Dickens, W.T. and Lang, K. (1993) 'Labor market segmentation theory: reconsidering the evidence', in W. Darity Jr (ed) Labor economics: problems in analyzing labour markets, Boston, MA: Kluwer Academic Publishers, pp 141-80.

Emmenegger, P., Hausermann, S., Palier, B. and Seeleib-Kaiser, M. (2012a) 'How we grow unequal', in P. Emmenegger, S. Hausermann, B. Palier and M. Seeleib-Kaiser (eds) The age of dualization: the changing face of inequality in deindustralizing societies, Oxford: Oxford University Press, pp 3-26.

Emmenegger, P., Hausermann, S., Palier, B. and Seeleib-Kaiser, M. (eds) (2012b) The age of dualization: the changing face of inequality in deindustrializing societies, Oxford: Oxford University Press.

Fagan, C., Kanjuo-Mrčela, A. and Norman, H. (2012) 'Young adults navigating European labour markets: old and new social risks and employment policies', in T. Knijn (ed) Work, family policies and transitions to adulthood in Europe, Basingstoke: Palgrave Macmillan, pp 130-54.

Gallie, D., Gebel, M., Giesecke, J., Halldén, K., Van der Meer, P. and Wielers, R. (2016) 'Quality of work and job satisfaction: comparing female part-time work in four European countries', International Review of Sociology, 26(3): 457-81. Available at: http://doi.org/10.1 080/03906701.2016.1181839

Hegewisch, A. (2009) Flexible working policies: a comparative review, Manchester: Institute for Women's Policy Research and Equal Human Rights Commission.

Hegewisch, A. and Gornick, J.C. (2011) 'The impact of work-family policies on women's employment: a review of research from OECD countries', Community, Work \& Family, 14(2): 119-38.

Hobson, B. (ed) (2014) Worklife balance: The agency and capabilities gap, Oxford: Oxford University Press.

Hobson, B. (2016) 'Gendered dimensions and capabilities: opportunities, dilemmas and challenges', Critical Sociology. Available at: http://doi.org/10.1177/0896920516683232

Hosking, A. (2010) The influence of children on female wages: better or worse in Australia?, Queensland: University of Queensland.

Javornik, J. and Kurowska, A. (2017) 'Parental leave as real opportunity structure for families and the source of gender and class inequalities', Social Policy \& Administration, 51(4): 617-37.

Kalleberg, A.L. (2000) 'Nonstandard employment relations: part-time, temporary and contract work', Annual Review of Sociology, 26(1): 341-65. Available at: http://doi.org/10.1146/annurev.soc.26.1.341 
Kangas, O. and Rostgaard, T. (2007) 'Preferences or institutions? Work family life opportunities in seven European countries', Journal of European Social Policy, 17(3): 240-56. Available at: http://doi. org/10.1177/0958928707078367

Knijn, T. (ed) (2012) Work, family policies and transitions to adulthood in Europe, Basingstoke: Palgrave Macmillan.

Korpi, W. (2010) 'Class and gender inequalities in different types of welfare states: the Social Citizenship Indicator Program (SCIP)', International Journal of Social Welfare, 19: S14-S24.

Lewis, J., Knijn, T., Martin, C. and Ostner, I. (2008) 'Patterns of development in work/family reconciliation policies for parents in France, Germany, the Netherlands, and the UK in the 2000s', Social Politics: International Studies in Gender, State \& Society, 15(3): 261-86. Available at: http://doi.org/10.1093/sp/jxn016

Martin, B., Hewitt, B., Baird, M., Baxter, J., Heron, A., Whitehouse, G. et al (2011) Paid parental leave evaluation: phase 1, Canberra: Research Publications Unit, Research and Analysis Branch, Australian Government Department of Families, Housing, Community Services and Indigenous Affairs.

Martin, B., Baird, M., Brady, M., Broadway, B., Hewitt, B., Kalb, G. et al (2014) PPL final report: paid parental leave evaluation, Brisbane: Institute for Social Science Research, The University of Queensland.

McDonald, P. (2013) 'Societal foundations for explaining low fertility: gender equity', Demographic Research, 28(34): 981-94. Available at: http://doi.org/10.4054/DemRes.2013.28.34

Merens, A. and Bucx, F. (2018) Werken aan de Start, Den Haag: The Netherlands Institute for Social Science Research, The University of Queensland.

Miani, C. and Hoorens, S. (2014) Parents at work: men and women participating in the labour force, Brussels: Rand Europe.

Mood, C. (2010) 'Logistic regression: why we cannot do what we think we can do, and what we can do about it', European Sociological Review, 26(1): 67-82. Available at: http://doi.org/10.1093/esr/jcp006

OECD (Organisation for Economic Co-operation and Development) (2017) Labour force statistics, Paris: OECD.

O'Reilly, J. and Fagan, C. (1998) Part-time prospects: an international comparison of part-time work in Europe, North America and the Pacific Rim, London and New York, NY: Routledge.

Palier, B. and Thelen, K. (2010) 'Institutionalizing dualism: complementarities and change in France and Germany', Politics E Society, 38(1): 119-48. Available at: http://doi.org/10.1177/ 0032329209357888 
Portegijs, W. and Keuzenkamp, S. (eds) (2008) Nederland deeltijdland. Vrouwen en deeltijdwerk, Den Haag: The Netherlands Institute for Social Research.

Portegijs, W. and Van den Brakel, M. (2016) Emancipatiemonitor 2016, Den Haag: The Netherlands Institute for Social Science Research, The University of Queensland.

Preston, A. and Yu, S. (2015) 'Is there a part-time/full-time pay differential in Australia?', Journal of Industrial Relations, 57(1): 24-47. Available at: http://doi.org/10.1177/0022185614545902

Prosser, T. (2016) 'Dualization or liberalization? Investigating precarious work in eight European countries', Work, Employment and Society, 30(6): 949-65. Available at: http://doi.org/10.1177/0950017015609036

Roeters, A. and Craig, L. (2014) 'Part-time work, women's work-life conflict, and job satisfaction: a cross-national comparison of Australia, the Netherlands, Germany, Sweden, and the United Kingdom', International Journal of Comparative Sociology. Available at: http://doi. org/10.1177/0020715214543541

Rose, J., Brady, M., Yerkes, M.A. and Coles, L. (2015) “'Sometimes they just want to cry for their mum": couples' negotiations and rationalisations of gendered divisions in infant care', Journal of Family Studies, 21(1): 38-56. Available at: http://doi.org/10.1080/132294 00.2015 .1010264

Summerfield, M., Bevitt, A., Freidin, S., Hahn, M., La, N., Macalalad, N. et al (2016) HILDA User Manual - Release 15, Melbourne: Institute of Applied Economic and Social Research, University of Melbourne. Treas, J., Van der Lippe, T. and Tai, T.-O.C. (2011) 'The happy homemaker? Married women's well-being in cross-national perspective', Social Forces, 90(1): 111-32. Available at: http://doi. org/10.1093/sf/90.1.111

Visser, J. (2002) 'The first part-time economy in the world: a model to be followed?', Journal of European Social Policy, 12(1): 23-42.

Watson, N. and Wooden, M. (2002) The Household, Income and Labour Dynamics in Australia (HILDA) Survey: Wave 1 survey methodology (HILDA project technical paper series, No. 1/02). Retrieved (2007) from Melbourne: www.melbourneinstitute.com/hilda/hdpstechn01.pdf

Whiteford, C.M. (2015) Early child care in Australia: quality of care, experiences of care and developmental outcomes for Australian children, Queensland: Queensland University of Technology.

Williams, J.C., Blair-Loy, M. and Berdahl, J.L. (2013) 'Cultural schemas, social class, and the flexibility stigma', Journal of Social Issues, 69(2): 209-34. 
Yerkes, M.A. (2009) 'Part-time work in the Dutch welfare state: the ideal combination of work and care?', Policy and Politics, 37(4): 535-52.

Yerkes, M.A. (2014) 'Collective protection for new social risks: childcare and the Dutch welfare state', Journal of Social Policy, 43(4): 811-28. Available at: http://doi.org/10.1017/S0047279414000385 Yerkes, M.A. and Den Dulk, L. (2015) 'Arbeid-en-zorgbeleid in de participatiesamenleving', Tijdschrift Voor Arbeidsvraagstukken, 31: 510-28.

Yerkes, M.A. and Javornik, J. (2018) 'Creating capabilities: Childcare policies in comparative perspective', Journal of European Social Policy. Available at https://doi.org/10.1177/0958928718808421

Yerkes, M.A. and Visser, J. (2006) 'Women's preferences or delineated policies? The development of part-time work in the Netherlands, the UK and Germany', in J.Y. Boulin, M. Lallement, J. Messenger and F. Michon (eds) Decent working time, new trends, new issues, Geneva: ILO, pp 235-62.

Yerkes, M.A., Martin, B., Baxter, J. and Rose, J. (2017) 'An unsettled bargain? Mothers' perceptions of justice and fairness in paid work', Journal of Sociology, 53(2): 476-91. Available at: http://doi. org/10.1177/1440783317696361 


\section{University Library}

\section{- M M N E R VA A gateway to Melbourne's research publications}

Minerva Access is the Institutional Repository of The University of Melbourne

Author/s:

Yerkes, M; Hewitt, B

Title:

Part-time strategies of women and men of childbearing age in the Netherlands and Australia

Date:

2019-06-26

Citation:

Yerkes, M. \& Hewitt, B. (2019). Part-time strategies of women and men of childbearing age in the Netherlands and Australia. Nicolaisen, $\mathrm{H}$ (Ed.). Kavli, H (Ed.). Jensen, R (Ed.). Dualisation of Part-Time Work The Development of Labour Market Insiders and Outsiders, Dualisation of Part-time Work: the development of labour market insiders and outsiders, (1), pp.265-288. Policy Press.

Persistent Link:

http://hdl.handle.net/11343/286366

License:

CC BY-NC-ND 